\title{
ANALISIS METODE MONTESSORI DALAM MENINGKATKAN KEMAMPUAN MEMBACA PERMULAAN SISWA SD/MI KELAS RENDAH
}

\author{
NuraAzkia ${ }^{1}$, Nur Rohman ${ }^{1}$ \\ ${ }^{\text {I }}$ Pascasarjana Pendidikan Guru Madrasah Ibtidaiyah, Universitas Islam Negeri Sunan Kalijaga \\ Yogyakarta, Indonesia \\ nuraazkia18@gmail.com
}

Naskah diterima: 1 Maret, 2020, direvisi: 30 Juni, 2020, diterbitkan: 30 Agustus, 2020

\begin{abstract}
Montessori is a method formulated based on Montessori theory that can be used in children's education and it is predicated on theories about child development. The most visible characteristic of this method is that it emphasizes the activities that are conducted by the child and focuses to adaptation process of child's learning development, as well as emphasizes the physic activities to improve practical skills. The primary aim of this research is describing how the Montessori method can prompt reading ability in the low grade of primary school. The method of this research is a library research, the data are analysed by using content analysis method. The main sources that used in this article are the writings of Maria which have been translated into Indonesian. The result of the research is the Montessori method can boost reading ability and overcome the limitations of knowing letter this grade. Thereby, the impact of the Montessori method can thrive cognitive, psychomotor, and affective skill particularly in low grade of primary school.
\end{abstract}

Keywords: Montessori method, Reading ability, Madrasah Ibtidaiyah

\begin{abstract}
ABSTRAK
Metode Montessori merupakan metode yang dirumuskan berdasarkan teori Montessori yang dapat digunakan dalam ranah pendidikan anak dan disusun berdasarkan teori tentang perkembangan anak. Karakteristik yang paling terlihat dari metode ini yaitu menekankan pada aktivitas yang dimunculkan oleh diri anak dengan menekankan pada proses adaptasi lingkungan belajar anak yang dibentuk sesuai dengan tahap perkembangannya, menggunakan peran dari aktivitas fisik dalam menyerap konsep pembelajaran untuk memiliki kemampuan yang praktis. Tulisan ini bertujuan untuk mendeskripsikan bagaimanakah metode Montessori dalam meningkatakan kemampuan membaca permulaan. Penelitian ini merupakan studi kepustakaan (library research), pembahasan dianalisis dengan menggunakan metode analisa isi (analysis content). Sumber yang digunakan dalam tulisan ini merupakan tulisan-tuliasan Maria yang telah diterjemahkan kedalam bahasa Indonesia. Hasil Penelitian terkait penerapan metode Montessori menggunakan aktivitas rangsangan sesuai dengan prinsip Maria Montessori ternyata dalam pembelajaran dapat meningkatkan kemampuan membaca siswa dan dapat mengatasi keterbatasan siswa dalam pengenalan huruf-huruf. Maka dengan menggunakan metode Montessori untuk belajar membaca diupayakan dapat membantu peserta didik dalam mengembangkan kemampuan kognitif, psikomotor, dan afektif yang terdapat pada diri peserta didik, dengan membuat anak dapat belajar sesuai dengan tingkat perkembangannya.
\end{abstract}

Kata Kunci Metode Montessori, Membaca permulaan, Madrasah Ibtidaiyah 


\section{PENDAHULUAN}

Pondasi dasar pada bagian akademik adalah keterampilan membaca. Membaca menjadi salah satu fungsi tertinggi yang berasal dari otak manusia sehingga dapat dikatakan bahwa setiap proses belajar didasarkan pada kemampuan membaca (Farida, 2007). Membaca menjadi media bagi anak untuk mengetahui dan mencari informasi. Sebelum anak mampu membaca dengan baik terlebih dahulu anak harus melakukan pengenalan huruf. Pengenalan huruf ini yang merupakan dasar diperlukan agar anak bisa membaca tulisan-tulisan yang terdapat pada bahan ang terdiri dari rangkaian-rangkain huruf. Tanpa mengenali huruf-huruf dengan baik, anak tidak mungkin bisa membaca dikarenakan huruf-huruf vokal merupakan pelajaran mendasar yang harus dikuasai oleh setiap anak untuk melanjutkan pelajaran lain.

Membaca permulaan terdapat dalam mata pelajaran bahasa Indonesia yang memiliki ruang lingkup mencangkup aspek berbahasa dan bersasrta yang digolongkan menjadi empat aspek antaralain aspek mendengarkan, aspek membaca aspek , berbicara dan aspek menulis (Badan Nasional Standar Pendidikan,2006). Sebenarnya keempat aspek tersebut dilaksanakan secara terpadu. Akan tetapi pelajaran bahasa Indonesia untuk kelas rendag khususnya di sekolah dasar lebih menekankan pada aspek kemampuan membacaca dan kemampuan menulis. Adapun tujuan utama dari membaca yaitu untuk mencari dan menemukan informasi, yang mencangkup isi dan pemahaman makna bacaan (Taringan, 1979).

Dengan demikian tidak dapat dipungkiri bahwa pembelajran membaca permulaan bagi anak yang terjadi di lapangan memiliki berbagai masalah, seperti : (1) kesulitan anak mengenali huruf, (2) membaca suara, pada : (a) membaca setiap kata per kata, (b) pemarafrasean yang keliru, (c) kesalahan pengucapan, (d) penggunakan gerak bibir,penggunaan jari telunjuk dan menggerakkan kepala (Slamet 2014). Dalam hal ini aktivitas membaca menjadi suatu yang kegiatan rumit bagi anak, karena melibatkan banyak hal, anak tidak hanya melafalkan tulisan namun juga dibarengi degan melibatkan aktifitas visual, berfikir, psikolinguistik

Kognitif (Farida, 2005).

Pada saat anak brusia 4-6 tahun anak mempunyai kepekaan yang baik belajar membaca. Jika diterapkan di sekolah dasar maka minimal anak berusia 6 tahun dan maksimal berusia 7 tahun. Karena pada saat usia ini peserta didik perlu diberikan rangsangan aktivitas yang dapat membantu anak dalam membaca, yang sesuai dengan perkembangannya. Adapun dalam hal ini Maria Montessori yang merupakan tokoh psikologi perkembangan memiliki cara-cara tersendiri untuk mengatasi permasalahan dalam membaca permulaan yang dikenal sebagai metode Montessori menjadi ciri khas pada pembelajaran. Dalam metode inipeserta didik melakukan aktivitas-aktivitas dengan menggunakan alat atau material dalam menunjung aktivitas belajar. Sehingga melalui aktivitas yang dilakukan, mampu meningkatkan kemampuan membaca sebagaimana prinsip-prinsip dalam teori Montessori itu sendiri. Beradasarkan permasalahan yang ada, maka penulis ingin mengkaji tentang peran metode montessori dalam meningkatkan membaca permulan untuk siswa sekolah dasar kelas rendah.

Pada kaitan ini peneliti menemukan penelitian yang memiliki kemiripan pada sebelumnya terkait metode montessori yang diteliti oleh Agus Sumitra bahwa dalam temuannya pelaksanaan pembelajaran dengan menggunakan metode montessori mengacu pada beberapa aspek pendidikan yang merupakan sebuah prinsipil terkait metode montossori yakni pentingnya asoek kebebasan, aspek struktur dan keteraturan, aspek 
realistis dan alami, aspek keindahan dan nuansa dan sapek alat bermain mintessori(Agus Sumitra, 2014).

Berangkat dari aspek penelitian diatas, peneliti ingin menganalisis kebaruan dan tambahan keberagaman tentang metode montessori dengan harapan menambah khazanah keilmuan terhadap pembaca. Dengan analisis yang mendalam terkait subtansi penelitian ini maka peneliti mengangkat judul "Analisis Metode Montessori Dalam Meningkatkan Kemampuan Membaca Permulaan Siswa SD/MI Kelas Rendah”.

\section{METODOLOGI}

Jenis penelitian yang digunakan dalam tulisan ini adalah studi pustaka (library research) yang mengandalkan bibliografi dari artikel ilmiah dan buku. Kemudian di integrasikan pada subtansi penelitian atau analisis isi (analysis content). Dalam metode kepustakaan ini peneliti tidak turun kelapangan untuk mengumpulkan data, tetapi menggunakan bahan-bahan kepustakaan seperti buku, artikel, dan bahan-bahan tulisan lainnya yang berhubungan dengan objek penelitian. Jenis data penelitian yang digunakan dalam penelitian ini berupa data kualitatif, data dijelaskan dalam bentuk narasi atau uraian bukan dalam bentuk angka yang dapat diuji dengan menggunakan prosedur statistik. Data ini juga menggambarkan fenomena berdasarkan sudut pandang suatu keilmuan, bahan ajar, informan, sehingg dapat menemukan sebuah pemahaman mengenai fenomena tersebut. Adapun teknik pengumpulan data yang digunakan dalam penelitian yaitu dokumentasi. Dokumen merupakan sejumlah besar fakta dan data yang tersimpan dalam bahan yang berbentuk dokumen. Sebagian besar data yang diambil oleh peneliti adalah sumber buku dan artikel yang bersifat primer dan sekunder. Analisis data yang digunakan dalam penelitian adalah didasarkan pada Miles and Huberman (Sugiyono, 2018) yaitu dilakukan secara interaktif melalui proses reduksi data (data reduction), penyajian data (data display) dan penarikan kesimpulan (verivication).

\section{HASIL DAN DISKUSI}

\section{Metode Montessori}

Maria Montessori merupakan tokoh pelopor yang menemukan metode montessori. Dalam hal ini metode Montessori tersusun berdasarkan pada teori perkembangan anak. Metode montesori merupakan suatu metode yang diterapkan untuk anak yang berada pada kelas rendah, metode ini bagian dari pengembangan teori-teori pendidikan yang disertai dengan teori perkembangan anak. Pada dasarnya metode ini mengutamakan tahap-tahap perkembangan anak. Pada metode lebih menekankan pada aktivitas yang ditampakkan oleh diri anak dengan berbantuan material atau alat yang dirancang dan menekankan pada proses adaptasi lingkungan belajar anak yang sesuai dengan level perkembangannya. Dalam hal ini aktivitas fisik yang dilakukan sangat berperan untuk membantu proses menyerap konsep pembelajaran dan mendapatkan kemampuan praktis. Dalam hal ini Montessori menyatakan bahwa pendidikan harus berjalan sesuai dengan perkembangan anak berdasarkan usia tertentu dengan cara memperhatikan tahap perkembangan individu anak (Montessori, 2008). Montessori mengindentifikasikan periode perkembangan secara umum menjadi tigabagian di antaranya:

a. Absorbent mind (0-6 tahun). Pada periode absorbent mind ini, anak mampu menyerap informasi dengan cepat dan menciptakan konsep pemahaman melalui pengalaman lingkungan, menggunakan bahasa, dan muncul secara perlahan terus 
berkembang dengan cara dilatih, diperkuat, disempurnakan, dan terus dikembangkan

b. Periode usia 6-12 tahun (periode kedua), Montessori disebut sebagaiperiode masa anak-anak

c. Periode usia 12-18 tahun (periode ketiga). Periode ketiga, seiring dengan usia remaja, terjadi perubahan fisik yang cukup besar dan menuju kematangan yang sempurna. Pada saat remaja setiap individu akan mencoba untuk memahami peran sosial maupun ekonomi dengan mencoba menemukan posisinya ditengah masyarakat (Gutek, 2004).

Pada periode pikiran menyerap (the absorbent mind), periode sensitive, dan proses nomalisai merupakan teori utama yang dipakai untuk memahami cara belajar anak. Hal ini sebagai pelengkap dalam menentukan hakikat kreatifitas alami dari kapasitas belajar yang terdapat dalam diri anak yang disebut pikiran menyerap (absorbent mind) dan beberapa fase perkembangan fisik yang disebut periode sensitive (Elizabeth).

Selanjutnya Maria Montessori mengemukakan bahwa dalam priode sensitive untuk perkembangan anak, meliputi 5 periode yaitu:

Tabel 1. Tabel periode perkembangan anak

\begin{tabular}{lll}
\hline No & Periode Sensitif & \multicolumn{1}{c}{ Perkembanngan Anak } \\
\hline 1 & Periode sensitive/peka untuk & Dikenal dengan penyerapan total (absorbent mind) \\
& keteraturan (usia 0-3 tahun & $\begin{array}{l}\text { perkenalan dan pengalaman sensoris yang berubungan } \\
\text { dengan panca indera. Anak mulai belajar keraturan. }\end{array}$
\end{tabular}

2 Periode sensitive untuk hal yang Pada tahap ini anak mulai mampu mendeteksi dan detail dan memfokuskan perhatiannya menemukan hal-hal kecil misalnya anak lebih detail pada hal yang kecil (usia 1-2 tahun) melihat adanya serangga kecil yang mungkin tidak diperhatikan oleh orang dewasa., Ketika mereka melihat suatu objek gambar, secara tidak sengaja mereka akan mengabaikan objek gambar yang paling utama dan teralihkan untuk memperhatikan hal kecil yang berada di latar belakang objek gambar utama.

3 Periode sensitive dalam hal menggunakan tangan / konsisten dalam menggenggam benda -benda yang disentuhnya (usia 18 bulan -3 tahun)
Pada tahap ini anak tertarik pada aktivitas membuka dan menutup benda benda dengan menggunakan seluruh telapak tangannya. Misalnya : Aktivitas yang dilakukan dengan memasukan material ke dalam suatu wadah, lalu menuangkannya dan memasukkannya kembali material material yang di gengam. Dua tahun berikutnya mereka memperbaiki gerakan serta indera sentuhan mereka. 


\begin{tabular}{|c|c|c|}
\hline 4 & $\begin{array}{l}\text { Periode sensitiveuntuk } \\
\text { movement/gerakan( usia 1,5-4tahun) }\end{array}$ & $\begin{array}{l}\text { Periode sensitive merupakan periode kepekaan yang } \\
\text { paling terlihat ketika anak mulai berjalan. Pada tahap ini } \\
\text { anak terkoordinasi pada perkembangan otot dan minat } \\
\text { pada benda-benda kecil. Kekuatan gerakan minat anak } \\
\text { pada kebenaran dan realitas menyadari urutan dalam } \\
\text { waktu dan ruang seperti Anak-anak terdorong oleh } \\
\text { implus yang tidak bisa dilawan dengan keinginanan } \\
\text { mereka untuk dapat berjalan, dan mereka berjalan } \\
\text { dengan bangga seolah-olah mereka telah mampu } \\
\text { menemukan caranya. }\end{array}$ \\
\hline 5 & $\begin{array}{l}\text { Periode sensitive untuk belajar } \\
\text { bahasa } \\
\begin{aligned} & \text { a. } \text { Secara tidak sadar (usia } 3 \\
& \text { bln - } 3 \text { thn). } \\
& \text { b. Secara sadar (usia } 3 \text { - } 6 \\
& \text { tahun) }\end{aligned}\end{array}$ & $\begin{array}{l}\text { Pada periode ini anak belajar berbagai kata-kata, dan tata } \\
\text { bahasa dari lingkungannya. Anak- mulai suka mengoceh } \\
\text { dengan kata kata tidak karuan terlebih dahulu sebelum anak } \\
\text { dapat berbicara dengan kata-kata yang bermakna. Setelah } \\
\text { itu anak masuk pada tahapan memadukan "kalimat dua kata," } \\
\text { baru kemudian anak mampu menguasai kalimat dengan } \\
\text { struktur yang lebih kompleks, anak mempelajari bentuk } \\
\text { gambaran tata bahasa baru dengan penuh kesadaran. Anak } \\
\text { peka dan mudah menerima pengaruh orang dewasa. Anak } \\
\text { mulai suka mencorat coret dan indra peraba mulai } \\
\text { berkembang. Minat membacanya mulai tumbuh. }\end{array}$ \\
\hline
\end{tabular}

6 Peride sensitive untuk Aspek Kehidupan Sosial (3 - 6 tahun)
Periode kepekaan ditandai dengan anak yang mulai 'aware'dengan teman satu grup. Saat mereka menyadari itu mereka mulai belajar bekerja sama dengan yang lain.

Sumber: (Montessori, 1964)

Mencermati penjelasan diatas bahwa secara optimal perkembangan anak menempuh periode sensitif atau masa peka dari usia 0-6 tahun yaitu ketika anak berada pada usia muda (Nurmalitasari, 2015). Hal ini sesuai dengan pernyataan Montessori bahwa dari sejak lahir hingga usia 6 tahun, anak memiliki daya serap yang tinggi ("absorbent mind"). Pada periode ini anak mempunyai kemampuan yang tinggi dalam membantu anak belajar dengan baik dan beradaptasi dari lingkungan dengan sendirinya. Pada masa ini anak akan mudah menerima sesuatu hal yang baru. Dalam memaksimalkan pendidikan anak Montessori mengenalkan berbagai material yang digunakan sebagai bahan, alat dan kegiatan yang khusus dirancang untuk merangsang kognitif anak.

Berdasarkan uraian tersebut dapat di pahami bahwa saat anak berusia 4 sampai 6 tahun anak mempunyai tingkat kepekaan yang baik untuk proses belajar membaca. Di karenakan usia untuk anak sekolah dasar berusia minimal 6 tahun dan maksimal berusia 7 tahun, maka pada perkiraan usia tersebut, siswa perlu diberikan rangsangan aktivitas yang dapat membantu siswa dalam membaca sesuai dengan perkembangan nya. Maka untuk siswa kelas $1 \mathrm{SD}$ anak memiliki kemampuan yang 
baik untuk belajar dan beradaptasi dari lingkungannya apabila diberikan berbagai aktivitas sebagai rangsangan untuk anak dapat belajar.

\section{Prinsip-prinsip pendidikan Montessori}

Montessori dalam pembelajaran menerapkan prinsip belajar bagi anak. Adapun yang menjadi prinsip-prinsip belajar Montessori sebagai berikut (Lillard, 2005) :

a. Pentingnya bentuk-bentuk interaksi guru terhadap anak.

b. Menekankan pada aktivitas aktivitas yang mengarah pada pengarahan diri pada anak melalui bantuan guru.

c. Memusatkan pada penyesuaian diri anak dari lingkungan sekitar sebagai bahan belajar yang sesuai dengan tingkat perkembangannya.

d. Aktivitas fisik yang berperan untuk membantu anak dalam menyerap konsep akademis dan keterampilan praktik.

e. Memanfaatkan peralatan yang otodidak yang digunakan sebagai alat memperkenalkan berbagai konsep.

f. Kebebasan dalam memilih dan memberikan kontrol diri.

g. Ketertarikan belajar anak, dalam hal ini anak akan dapat belajar dengan lebih baik jika mereka telah tertarik pada apa yang mereka pelajari.

h. Menghindari penghargaan ekstrinsik

i. Pembelajaran kolaboratif antar teman sebaya.

j. Pembelajaran dalam konteks akan lebih mendalam dan lebih memperkaya daripada pembelajaran abstrak,

Berdasarkan penjelasan tersebut, dapat dipahami perkembangan anak dilalui dengan serangkaian perubahan terjadi pada anak yang berlangsung secara secara bertahap dan bersifat tetap dari segi fungsi-fungsi jasmaniah dan rohaniah yang dimiliki setiap individu saat menuju pada tahap kematangan melalui tahap pertumbuhan dan belajar. Perkembangan siswa kelas I (usia 6-7 tahun) masuk dalam tahap perkembangan operasional konkret, dan dikembangkan untuk mempertajam kemampaun mereka. Oleh karena itu alat atau material yang konkrit sangat dibutuhkan untuk memberi rangasangan sehingga mampu membantu menunjuang proses belajar anak pada usia perkembangan 6-7 tahun.

Metode Montessori mempunyai berbagai bentuk material, yang dimaksudkan adalah alat beserta ragam aktivitas yang digunakan untuk menunjang proses belajar anak dengan proses perkembangan anak yang dibentuk melalui alat yang disediakan. Sebelum menjelaskan bagaimana ragam aktivitas dan materialnya, dalam hal ini akan lebih dulu mengetahui beberapa prinsip dalam penggunaan material sebagai berikut :

a. Setiap material mempunyai tujuan dan bermaknana bagi anak.

b. Setiap matreial yang digunakan harus sesuai dengan perkembangan anak misalnya dari sederhan kerumit dalam desain dan penggunaannya,

c. Setiap benda atau material dirancang guna untuk menyiapkan anak belajar secara tidak sadar terkait hal-hal yang akan dihadapi anak ke depan.

d. Setiap benda yang diberikan pada anak harus diberikan mulai dari hal yang kongkrit sampai mengarah kepada hal ke yang abstrak yang dilakukan secara bertahap . 
e. Setiap alat material dirancang bertujuan untuk mendapatkan auto-edukasi. Artinya kontrol kesalahan berada pada benda tersebut bukan pada guru. Kontrol kesalahan ini akan membimbing anak dalam menggunakan benda tersebut dan memiliki kemungkinan anak dapat menyadari kesalahannya sendiri dan memperbaikinya dengan sendirinya.

Dengan demikian dalam proses pembelajaran Montessori, dilakukan dengan cara memberikan aktivitas-aktivitas dengan menggunakan material material tertentu sehingga terjadinya rangsangan dan pengalaman untuk siswa, dalam pembelajaran Montessori memberikan rangsangan melalui material sesuai dengan tahap usia perkembangan anak.

\section{Membaca Permulaan}

Tzu dalam Ahmad Susanto menjelaskan bahwa membaca merupakan suatu kemampuan dalam menerjemahkan suatu lambang huruf ke dalam bentuk suara yang digabungkan dengan beberapa kata-kata, Sehingga Kata-kata yag telah disusun tersebut dapat dipelajari dan dipahami (Susanto, 2011). Adapun Steinberg dalam Ahmad Susanto menjelaskan bahwa membaca permulaan merupakan aktivitas membaca yang diajarkan secara terprogram kepada anak, fokus pada perkataan-perkataan utuh dan bermakna dalam pribadi anak-anak, melalui konsep permainan dan berbagai aktivitas yang menarik digunakan sebagai perantara proses pembelajaran.

Berdasarkan beberapa pendapat di atas dapat dipahami bahwa membaca permulaan dalam tulisan ini yaitu suatu upaya yang dilakukan anak duntuk melafalkan setiap simbol (huruf) yang diajarkan secara terancang melalui kegiatan dan aktivitas yang menarik bagi anak sebagai perantara pembelajaran.

Sebagaimana yang diungungkapkan oleh Rubin dalam Slamet yakni mengenai aktivitas yang dilaksanakan dalam praktik pengajaran membaca antara lain: (1) kesadaran fonem (bunyi bahasa), (2) peningkatan ucapan (3) hubungan antara huruf-huruf merupakan prasyarat untuk dapat membaca, (4) membedakan bunyi-bunyi merupakan hal penting dalam pemerolehan bahasa, khususnya membaca,(5) kemampuan mengingat, (6) membedakan huruf, (7) orientasi ke kiri dan ke kanan, (8) keterampilan pemahaman, dan (9) penguasaan kosakata (Slamet, 2014).

Pembelajaran membaca di Sekolah Dasar diperuntukkan untuk kelas 1 karena kelas tersebut masuk dalam kategori kelas rendah yang terdapat pada mata pelajaran bahasa Indonesia yang mengutamakan pada aspek peningkatan kemampuan membaca dan kemampuan menulis permulaan, sedangkan untuk kelas tinggi menekankan pada peningkatan kemampuan berkomunikasi lisan dan tulis. Membaca permulaan dalam pembelajaran membaca dengan baik adalah pembelajaran membaca yang didasarkan pada kebutuhan anak dengan mempertimbangkan kemampuan yang telah dimiliki anak.

\section{Faktor yang Mempengaruhi Kemampuan Membaca}

Menurut Lamb dan Arnold dalam Farida, ada tiga faktor yang mempengaruhi kemampuan membaca permulaan yaitu faktor fisiologis, intelektual dan psikologis. Dalam penjelasan sebagai berikut :

a. Faktor fisiologis yang mencangkup kesehatan fisik, pertimbangan neurologis, dan jenis kelamin seperti gangguan pada alat bicara, alat pendengaran dan alat 
penglihatan dapat berpengaruh dengan keterlambatan kemajuan belajar membaca pada anak. Analisis bunyi mungkin akan sulit ditangkap oleh anak yang mempunyai masalah pada alat bicara dan alat pendengaran.

b. Faktor intelektual anak memang dapat mempengaruhi berhasil atau tidaknya anak untuk memiliki kemampuan membaca. Namun hal ini tidak sepenuhnya dapat disalahkan. Karena kemampuan anak dalam berpikir bisa saja dapat di sebabkan oleh faktor metode mengajar guru, prosedur, dan kemampuan guru juga turut mempengaruhi kemampuan membaca pada anak.

c. Faktor lingkungan juga akan mempengerahui pada kemajuan kemampuan membaca anak. Hal ini mencangkup bagaimana latar belakang dan pengalaman yang anak dapatkan di rumah, dan bagaimana kondisi status sosial ekonomi keluarga peserta didik. Dalam hal ini dangat menentukan keberhasilan kemampuan pembelajaran membaca permulaan di sekolah dasar yang dipengahuhi oleh berbagai faktor internal maupun faktor eksternal. Seorang guru harus bersikap cermat untuk mendeteksi segala bentuk hambatan tersebut sedini mungkin agar pemberian materi, strategi dan media pembelajaran dapat disesuaikan. (Farida, 2007)

\section{KESIMPULAN}

Peran metode montessori dalam meningkatkan kemampuan membaca yaitu memberikan aktivitas yang mampu memberikan rangsangan dan pengalaman untuk memperkaya pikiran penyerap atau disebut (Absorbent mind), memenuhi kebutuhan periode sensitif dan struktur intelektual dalam belajar, sekaligus mengikuti proses belajar. Perkembangan siswa kelas I (usia 6-7 tahun) masuk dalam tahap perkembangan operasional konkret, dan dikembangkan untuk mempertajam kemampaun mereka. Oleh karena itu alat atau material yang konkrit sangat dibutuhkan untuk memberi rangasangan sehingga mampu membantu menunjuang proses belajar anak pada usia perkembangan 6-7 tahun. Metode Montessori dalam meningkatkan kemampuan membaca permulaan, siswa diberikan benda atau material berupa kartu kata, gambar, dan benda-benda konkrit dan melakukan pelafalan huruf suara fonetik dalam mengenal huruf dan bunyi, dikarenakan cara belajar tersebut sesuai dengan tahap perkembanagan anak untuk menerima dan menyerap pembelajaran, khususnya dalam pembelajaran membaca permulaan.

\section{ACKNOWLEDGMENT}

Penulis ucapkan beribu-ribu terima kasih kepada dosen pembimbing dan pihak sekolah yang telah membantuk terlaksananya penelitian ini sampai selesai serta temanteman yang tidak bisa saya sebutkan satu persatu yang memberikan kontribusi pemikiran terhadap penelitian library research ini.

\section{BIBLIOGRAPHY}

Ahmad Susanto. (2011). Perkembangan Anak Usia Dini: Pengantar Dalam Berbagai Aspeknya. Jakarta: Kencana.

Badan Nasional Standar Pendidikan BNSP, (2006), Kurikulum Tingkat Satuan Pendidikan Tingkat SD,MI, dan SD-LB, Jakarta : BNSP.

Elizabeth G.Hainstock, Kenapa Montessori. Jakarta : P.T. Pustaka Delapratasa.

Farida Rahim, (2005) Pengajaran Membaca Di Sekolah Dasar, Jakarta: PT Bumi Aksara. 
Gutek, G.L (2004). The Montessori Method : The Origin Of An Educational Innovation, Including An Annotated Edition Of Maria Montessori's The Montessori Method. Lanham : Rowman \& Littlegfield Publisher.

Lillard, A.S. (2005). Montessori the science behind the genius. New York: Oxford University

Maria Montessori, (2008). The Absorbent Mind (Pikiran Yang Mudah Menyerap), Yogyakarta: Pustaka Pelajar.

Maria Montessori. (1964), The Montessori Method. Schoken Books : New York USA

Nurmalitasari, Femi. 2015, Perkembangan Sosial Emosi Pada Anak Usia Pra Sekolah. Buletin Psikologi, Vol 23 No 2, 103-111

Sumitra Agus, 2014, Proses Pembelajaran Berbasis Metode Montessori Dalam Mengembangkan Keterampilan Sosial Anak Usia Dini, Jurnal Empowerment, Vol 4 No 1, 60-70

Preschool dengan Metode Montessori, di akses dalam laman : "http://www.uniquegrowingmind.com/index.php/montessori. $\quad$ Pada tanggal 19 Mei 2019.

Rahim Farida. (2007) Pengajaran Membaca Di Sekolah Dasar. Jakarta: Bumi Aksara. Slamet (2014). Pembelajran Bahasa dan Sastra Indonesia di Kelas Rendah dan Tinggi Sekolah Dasar. Surakarta: UNS Press.

Sugiyono. (2018). Metode Penelitian Kualitatif. Bandung: Alfabeta

Taringan, (1979). Pengajar Ejaan Bahasa Indonesia. Bandung: Angkasa. 